\title{
Glaciology in Aberdeen
}

Brice R. Rea*, Alastair M.D. Gemmell and Matteo Spagnolo

Geography and Environment, School of Geosciences,

University of Aberdeen, Aberdeen, UK.

* - corresponding author (b.rea@abdn.ac.uk) 


\title{
Glaciology in Aberdeen
}

\begin{abstract}
The Department of Geography has been engaged with glaciological research from its early beginnings. The paper concentrates on the period from the appointment of Chalmers Clapperton in 1962 onwards, which coincides with the time when academic staff developed focused areas of research expertise. A brief biography of each of the eleven academic members of staff who worked in the area of glaciology is presented. This is followed by an overview of the recurring research themes and locations which have been revisited within glaciology over the years. It aims to provide an overview and flavour of the Department's glaciological research.
\end{abstract}

Keywords glaciology, Department of Geography, Aberdeen

\section{Introduction}

Glacial publications date from the early days of a recognisable Department of Geography (e.g. Bremner 1934, 1939) and glaciology has had a continual presence since the arrival of Chalmers Clapperton in 1962. We first present short biographies of the academic members of staff who have contributed to Aberdeen's glaciological legacy. Subsequently we identify and elaborate on some of the research areas and themes which appear, disappear and reappear across the years while those individuals worked in Aberdeen. There are too many PhD students and post-doctoral staff to 
mention, bar one individual who has a recurrent presence. We have tried to be as inclusive as possible but apologise to anyone who is not named and feels that they should have been.

\section{The glaciology staff chronology}

Chalmers Clapperton joined the Department of Geography at Aberdeen in academic year 1962-63 after having studied at Edinburgh University both as an undergraduate and as a postgraduate. Chalmers brought skills and enthusiasm to the post, as well as a formidable work ethic and a personality which endeared him rapidly to both colleagues and students. He soon expanded the geographical range of his field research areas from his native Scottish borders into the north-east of Scotland, and from there to the Polar environments of Iceland and Svalbard. Following the appointment of David Sugden to the Department, the two of them found a mutual enthusiasm for all things glacial and thus began an extensive and most fruitful research partnership. In the course of their research, they further extended the scope of Aberdeen-based glacier-related research to the Southern Hemisphere (Clapperton \& Sugden, 1982; Clapperton, 1990). Chalmers' work was expanded into landforms of tectonically-active environments. His work in the Andes and other parts of Latin America ultimately culminated in a major book Quaternary Geology and Geomorphology of South America (Clapperton, 1993), which is still regarded as the "bible" on this topic. His field work was not without risk and it appeared for a time that he was perhaps the catalyst for major natural events. He was in Peru around the time of the major earthquake in 1970 which devasted huge tracts of that country, and later visited Heimaey, off the south coast of Iceland, when a major volcanic eruption (1973) threatened to engulf the local fishing port in ash and lava. Chalmers loved nothing better than being in the field making new discoveries or 
introducing others to those discoveries and he enthused a multitude of students with his teaching. In 1998 Chalmers suffered a severe stroke and did not recover sufficiently to return to work. Sadly, he passed away on the $23^{\text {rd }}$ of October 2018 (Sugden, 2019).

In 1966 David Sugden was appointed to the Department. The location was ideal as his doctoral thesis, undertaken at Oxford University, had been on glacial erosion in the Cairngorms. David had already participated in student expeditions to Norway, Iceland and East Greenland. Early publications, while in Aberdeen, included seminal work on the Cairngorms and the selectivity of glacial erosion (Sugden \& Watts, 1977). Together with Chalmers he undertook work in the Southern Hemisphere in the subAntarctic islands and the Antarctic Peninsula (Sugden \& Clapperton, 1980). While in Aberdeen, in collaboration with fellow Oxford undergraduate Brian John (then at Durham), David co-wrote Glaciers and Landscape (Sugden \& John, 1976), the benchmark glacial geomorphology textbook for the next two decades. David next pioneered research developing computer models to link patterns of glacial landforms to modelled distributions of glacier bed conditions beneath ice-sheets in Greenland and in the area covered by the former Laurentide ice-sheet. It was at this time that David left the Department and moved to the University of Edinburgh where he remained for the rest of an illustrious career. It was perhaps fitting that he received the prestigious Seligman Crystal award of the International Glaciological Society in 2012, during the annual meeting, that year hosted by the glaciologists in Aberdeen.

Alastair (AI) Gemmell was appointed to a lectureship in geomorphology at Aberdeen University in 1973. Al had been an undergraduate in the Department (196468), when he also participated in the "Aberdeen University Expedition to Greenland" (Sugden, 1968a), an undergraduate expedition to the Sukkertoppen area of West Greenland, led by David Sugden. Al completed his $\mathrm{PhD}$ at the University of Glasgow in 
1971 (The Glaciation of the Island of Arran). He subsequently had a brief appointment as a Teaching Assistant in Glasgow, and then returned to a lectureship in Aberdeen, in 1973. His research in Aberdeen focused on the Quaternary history of the north-east of Scotland with respect to the possibility of there having been an unglaciated enclave in the Buchan area of Aberdeenshire. Al produced a range of publications on this over the years, working with colleagues including Chalmers Clapperton (Kesel \& Gemmell, 1981; Clapperton \& Gemmell, 1998; Gemmell \& Stove, 1999; Rea \& Gemmell, 2009;). $\mathrm{Al}$ also led the development of an Aberdeen luminescence dating facility in the early 1980s. The lab expanded in the early 1990s and the new equipment led to benchmark papers demonstrating for the first time that the accuracy of luminescence dating of glacial and fluvioglacial sediments varied according to sediment transport history (Gemmell, 1988; 1994; 1997; 1999). Al retired from the University in 2011.

The appointment of Judith Maizels in 1979 marked a further expansion in glaciological research capacity in the Department. Judith came north from London to Aberdeen with research interests in fluvioglacial geomorphology of the Alps (Maizels, 1979), with particular emphasis on the sedimentology and sedimentary structures of meltwater stream deposits. Judith continued the tradition of field-based research completing a sustained period of very detailed research into glacifluvial structures and sediments in southern Iceland. Judith focussed much of her attention at this time on glacial meltwater streams and the sediments linked to jökulhlaup (glacier burst) activity (Maizels, 1989a, 1992, 1993, 1997). The resultant data were used to construct theoretical models of the sequence of events during such floods. Judith's research interest remained with massive flood deposits, which she then studied in New Zealand (Maizels, 1989b) and, even more adventurously, to inform a study of Plio-Pleistocene raised channel deposits in the Wahiba area of Oman (Maizels, 1990). Judith had a 
ferocious appetite for research which extended from the cold and warm deserts of the world to her own kitchen, where she conducted experiments to test theories on the generation of kettle holes using an oven and ice. Judith left the Department in 1995.

In 1993 Doug Benn joined the Department as a lecturer. Doug had moved up the road a short distance following a $\mathrm{PhD}$ and a post-doctoral fellowship at the University of St Andrews. Doug brought with him an exceptional enthusiasm for all things glacial and the Scottish landscape, an ideal person to team up with Chalmers Clapperton. His expertise in sedimentology and ability to innovate led to the publication of a series of seminal papers which transformed the analysis and interpretation of glaciogenic sediments (e.g. Benn, 1994a, 1994b; Benn \& Ballantyne, 1994; Benn \& Evans, 1996). Doug began working in the Himalayas and in South America while in Aberdeen, producing highly cited publications (Clapperton et al., 1997; Benn \& Owen, 1998). Teaming up with Al Gemmell, they produced a transformational tool for palaeoglaciology (Benn \& Gemmell, 1997). If that were not enough, Doug also coauthored the new "bible" of glacial geomorphology, Glaciers and Glaciation (Benn \& Evans, 1998). Doug is now back down the road at the University of St Andrews and continues research collaborations with colleagues in Aberdeen.

Nick Spedding arrived in the Department as a lecturer in 1995, coming via a $\mathrm{PhD}$ in Edinburgh, supervised by David Sugden, closing the Aberdeen loop. Nick joined Al Gemmell, Doug Benn and Chalmers Clapperton in glaciology, bringing strengths in glacial hydrology and sedimentology to the team, along with a passion for statistical analyses and an integrated approach to research in glaciological processes, landforms and landsystems. Nick published a number of highly cited glacial sedimentology papers (Kirkbride \& Spedding, 1996, Swift et al., 2002; Spedding \& 
Evans, 2002) while impressively contributing publications on the more philosophical side of physical geography (Spedding, 1997, 1999).

In 2002, Douglas (Doug) Mair joined the Department as a lecturer, after completion of a Leverhulme Trust post-doctoral fellowship at the University of Alberta, in Canada. Doug gained his $\mathrm{PhD}$ from Cambridge University, under the co-supervision of Martin Sharp (who had himself completed his $\mathrm{PhD}$ at Aberdeen under the supervision of Chalmers Clapperton and David Sugden). Doug brought a new focus on contemporary glaciology processes, thus reinvigorating glaciological research. His main interests were surface mass balance, subglacial hydrology and glacier and ice sheet dynamics. While at Aberdeen, Doug was involved in a pioneering NERC Consortium grant focused on the calibration and validation of satellite-derived measurements of glaciers and ice sheets. Subsequently, he worked on an ambitious project linking surface melt, subglacial hydrology and ice dynamics of terrestrial terminating margins of the Greenland Ice Sheet and then an interdisciplinary study reconstructing the millennial scale history of a large tidewater outlet glacier in SW Greenland. Doug authored multiple highly cited papers during his time in the Department (Mair, 2004; Bartholomew et al., 2010, 2011a and b, and 2012; Sole et al., 2011, 2013; Chandler et al., 2013). Doug, now Head of the School of Environmental Sciences at the University of Liverpool, continues to collaborate with colleagues in Aberdeen.

The group expanded again in 2004, with the arrival of Brice Rea via a $\mathrm{PhD}$ from Queen's University Belfast (QUB) and post-doctoral positions at QUB, Cardiff University and the University of Leicester. Brice brought strengths in palaeoglaciology, periglacial processes and glacier-climate interactions. At Aberdeen, Brice has led an international team working on a Europe-wide reconstruction of palaeoglaciers during the Younger Dryas while developing a suite of GIS tools for this purpose (Pellitero- 
Ondicol et al., 2015, 2016). He wrote a benchmark paper providing a global and regional datasets of AABRs (area altitude balance ratios, Rea (2009)) to be used for determination of the equilibrium line altitude on glaciers. He has undertaken a significant amount of work in Greenland developing glacial histories across multiple timescales (Roberts et al., 2013). He has also worked in the subsurface world via seismic and cores. Initially this work was focused on the Cenozoic history of the Arctic Ocean (e.g. Moran et al., 2006; Sluijs et al., 2006). Subsequently, the North Sea became an area of interest, with the reconstruction of environmental histories over the past 2.6 million years and the rewriting of the glacial history for the region (Rea et al., 2018). He continued working on surging glaciers from both process- (Rea and Evans, 2011) and palaeo-perspectives (Evans et al., 2008).

Alastair Dawson joined the Department in 2005 from Coventry University, becoming the Assistant Director of the Institute for Coastal Science and Management. Alastair was an Aberdeen Geography graduate and his doctorate was from Edinburgh. He brought expertise in geomorphology, coastal processes and change, and palaeoclimatology and expanded the glaciology group to become the current Cryosphere and Climate Change cluster. He retired in 2014 but during his time in Aberdeen he published some very high profile papers, for example on tsunami deposits (Dawson \& Stewart, 2007; Dawson et al., 2007; Kortekaas \& Dawson, 2007; Costa et al., 2012) and the use of Greenland ice core records (Dawson, et al., 2007; Dugmore et al., 2007), as well as a book devoted to the climate of Scotland (Dawson, 2009).

Robert (Rob) Bingham was appointed lecturer in 2009 as part of the University of Aberdeen's $6^{\text {th }}$ Century 100 new posts initiative. Rob had previously been a Research Scientist at the British Antarctic Survey and a post-doctoral researcher at the NERC Centre for Polar Observation and Modelling in the University of Bristol. He gained his 
$\mathrm{PhD}$ in glaciology at the University of Glasgow, co-supervised by Martin Sharp, completing another Aberdeen loop. Over four years in Aberdeen, Rob led projects in Antarctic science and especially contemporary ice-sheet dynamics and their controls, investigated through a suite of field observations utilising geophysical techniques and satellite remote sensing. Notable outputs were the discovery of Antarctica's "Ferrigno Rift" (Bingham et al., 2012) and publications on the shape and evolution of the glacier bed in key sectors of West Antarctica such as Pine Island Glacier (Smith et al., 2012) and the Robin Subglacial Basin (Ross et al., 2012). Robert has continued to collaborate with the Aberdeen Cryosphere and Climate group since moving to Edinburgh (e.g. Bingham et al., 2017).

Matteo Spagnolo joined the Cryosphere and Climate Change group in 2009 as a lecturer, coming from a post-doctoral position at the University of Sheffield, and having completed a $\mathrm{PhD}$ at the University of Genova. Matteo brought a broad academic background, spanning biology and geology, and had spent much of his career in Italy studying alpine environments. Matteo also brought expertise in GIS and the morphometric analyses of landscapes, and a newly acquired fascination with the world of ice sheet subglacial landforms. He continues to work on alpine and ice sheet glacial processes, at regional to continental scales, driven by a relentless curiosity and wonder for the environment. He has led a benchmark project investigating mega-scale glacial lineations (Spagnolo et al., 2014; 2016; 2017), he has conducted many studies on cirques (Barr \& Spagnolo, 2015) and is now spearheading the glacier-volcano research in the Department (Barr et al., 2018). He has strong international academic links, recently focusing on the development of a new paleoclimate proxy with the University of California at Berkeley (Tremblay et al., 2019) and new analytical approaches to morphometry, with the University of Texas at Austin (Spagnolo et al., 2017a). 


\section{Making a mark and recurring themes}

An overview of glaciology research at the University of Aberdeen reveals a number of themes and areas of interest that connect across the years. In its infancy, the strengths in glaciology lay in the study of the glacial landscape of Scotland and what is now known as palaeoglaciology, led by the formidable duo of Chalmers Clapperton and David Sugden. There was also a desire to deepen understanding of the origin of that landscape through investigations of glacial processes in contemporary glaciated landscapes, exemplified by the "Aberdeen University Expedition to Greenland in 1968" (Sugden, 1969a) (Figure 1). Integration of contemporary with palaeoglacial research has remained a cornerstone for those who subsequently worked in glaciology in Aberdeen, continuing until the present day, with the most recent field campaigns focusing on Greenland and the Alps. Ground breaking fieldwork, and related publications, were delivered early on by Chalmers and David working in the Southern Hemisphere, most notably on South Georgia (Figure 2) and the Antarctic Peninsula (Sugden and Clapperton 1981; Clapperton and Sugden, 1982). An interest in Antarctica returned to the glaciology group in Aberdeen via the largely field-based work of Rob Bingham, the remote sensing investigations of Matteo Spagnolo, and the collaboration between the two (Spagnolo et al., 2014, 2017; Jamieson et al., 2016; Livingstone et al., 2016; Bingham et al., 2017; Davies et al., 2017, 2018).

\section{Landforms and Sediments}

Early work on glacial landforms relied heavily on morphometry, linking landforms to observations from modern landscapes. As the subject developed, increasing use was 
made of process-form relationships and sediment-landform associations, which required greater use of sedimentology. Initially in Aberdeen this was led by Judith Maizels working on sandur, braided river and jökulhlaup deposts, leading to the publication of a number of highly cited works (Maizels, 1989a, 1993, 1997). With the arrival of Doug Benn, innovative sedimentological approaches were applied to the study of glacial sediments, leading to the publication of benchmark research (Benn, 1994a, 1994b, Benn and Ballantyne 1994, Benn and Evans, 1996). Nick Spedding, who joined the Department in 1996, added further to the expertise in sedimentology within the team. Nick contributed a number of significant works related to the debris transport pathways in glaciers (Figure 3) and glaciated valley landsystems (Kirkbride \& Spedding, 1996, Swift et al., 2002; Spedding \& Evans, 2002).

\section{Remote Sensing and GIS}

The development of remote sensing and GIS techniques represents one of the most important advances in geospatial sciences and both have become increasingly prominent in glaciological research since the 1990s. This move was reflected in the work undertaken in the Department. Doug Mair, for example, was involved in pioneering work, in the Canadian Arctic and on the Greenland Ice Sheet, to calibrate and validate data from CRYOSAT, a cryosphere-dedicated satellite (Figure 4). The revolution in remote sensing and the generation of imagery and digital elevation models has seen a return to the morphometric techniques employed by previous generations of researchers. However, mapping is now possible over what were once unimaginably large spatial areas and without the need for ground survey. All that the new technologies required was a workstation, satellite images or digital terrain models and dedication. With the arrival of Matteo Spagnolo, one of the leading exponents of these techniques, 
Aberdeen began to deliver high quality research in this area of glaciology (Figure 5). These techniques can generate very large datasets that have led to considerable improvements in our understanding of the formation of subglacial landforms, such as drumlins and mega-scale glacial lineations (MSGL). They can also shed light on ice sheet dynamics and ice-bed interactions beneath glaciers, ice streams and ice sheets (Ely et al., 2017; Spagnolo et al., 2012, 2014, 2017).

Rob Bingham provided an additional piece of the remote sensing jigsaw, bringing geophysical skills in radar glaciology (Figure 6) to investigate the beds of ice sheets (Fretwell et al., 2013). Knowledge of the bed of extant ice sheets was initially limited to a few boreholes and seismic lines, but airborne and surface acquired radar data has completely revolutionised our understanding of the subglacial landscape and bed conditions (ibid.). Robert saw the importance of combining the skills of palaeo and contemporary glaciology for advancing our understanding of processes at the ice-bed interface (Bingham \& Seigert, 2009). The fortuitous coincident arrival of Robert and Matteo in Aberdeen facilitated further collaboration in this area, resulting in many significant publications, and improved understanding of ice stream dynamics (Bingham et al., 2017, Davies et al., 2017, 2018).

\section{Ice Sheets and ice streams}

The study of ice sheet dynamics through their arterial drainage systems of ice streams and outlet glaciers has been an enduring theme over the past two decades in Aberdeen. Our researchers have brought together their skills in subglacial processes, glacial geomorphology, ice dynamics, remote sensing, morphometry and many more, to advance understanding. It has become apparent that subglacial hydrology plays a key role in governing ice sheet dynamics in a system previously thought to be relatively 
invariant. Doug Mair co-led research on the Greenland Ice Sheet identifying clear connections between surface melt, the subglacial drainage system and ice dynamics (Bartholomew et al., 2010; 2011a, b; 2012; Chandler et al., 2013; Sole et al., 2011; 2013). Doug and Brice Rea have brought together their glaciological expertise to develop centennial to millennial scale records of ice sheet change in Greenland (Figure 7). This has generated a dataset which is suited for calibration and validation of numerical models of tidewater glacier dynamics over timescales significantly beyond the instrumental record. These are necessary in order to improve confidence in model predictions 50 or 100 years from now. Matteo and Brice also worked together on a project in Poland, investigating the bed of a palaeo ice stream. They applied state of the art sedimentological techniques, such as anisotropy of magnetic susceptibility and x-ray tomography, combined with detailed investigations of large-scale field excavations (Figure 8), to elucidate the processes occurring during ice streaming at the ice bed interface and concomitant landform generation (Spagnolo et al., 2016).

\section{Tool development}

Glaciology at Aberdeen has a history of the development of bespoke research tools, provided to the community through publications and open access downloads.

Palaeoglacier reconstruction has long been an Aberdeen strength and Doug Benn and Al Gemmell with their paper "Calculating equilibrium-line altitudes of former glaciers by the balance ratio method: a new computer spreadsheet" (Benn \& Gemmell, 1997) provided, for the first time, the means of determining the ELA for palaeoglaciers using the AABR method, which has been shown to be superior, in many instances, to the more widely used accumulation area ratio method. The use of this tool was further enhanced by publication, in 2009, of a dataset of global, regional and climate-type 


\begin{abstract}
AABRs by Brice Rea (Rea, 2009). More recently Aberdeen developed two bespoke toolboxes that can, with a little GIS knowledge, a digital elevation model and a mapped glacier end moraine, rapidly reconstruct a 3D palaeoglacier surface (Figure 9) and extract a palaeo-ELA (Pellitero et al., 2015; 2016). This tool has been used to generate regional datasets of palaeoglacier ELAs, which are now being used to investigate largescale atmospheric circulation, expanding the utility of glacier reconstructions. Another recently developed tool, connects back to early work in the Department by David Sugden on corries (cirques) (Sugden, 1969b). This tool allows the rapid analyses of glacial cirque metrics (Figure 10) and spatial distributions (Spagnolo et al., 2017b), once again producing large datasets which can be analysed with statistical rigour, providing links to palaeoclimate and landscape evolution (Barr et al., 2017; Barr et al., in press).
\end{abstract}

\title{
Palaeoglaciers, dating and climate
}

Our understanding of present-day climate change requires contextualisation from past events and time periods. As highlighted above, numerical models used for future forecasting require robust calibration and validation data. The palaeo-environmental and landform record can provide these much-needed data (Gemmell et al., 2007; Gemmell \& Spötl, 2009). Glaciers have been demonstrated to be an important climate proxy. Aberdeen has a long track record of palaeoglaciology and has been active, over the past two decades, in pushing the science into the realm of a truly quantitative palaeoclimate proxy (Benn \& Gemmell, 1997; Rea, 2009; Pellitero et al, 2015, 2016; Spagnolo \& Ribolini, submitted). In all of these studies chronology is paramount for understanding the timing and rates of environmental change. Earlier work in the Department relied solely on the use of radiocarbon dating to provide this much needed chronology. 
Subsequently, under the leadership of Al Gemmell, the Department established its own luminescence laboratory. Al operated the lab for three decades, generating some important publications (Gemmell, 1988, 1997). More recently Brice Rea and Matteo Spagnolo have relied heavily on cosmogenic nuclide exposure dating to provide a chronology for palaeoglacier reconstructions. Aberdeen has been using various approaches, to chronologically constrain ice dynamics and to generate quantitative palaeoclimate data (Rea \& Evans, 2007, Rea 2009, Pellitero et al, 2015, 2016, Federici et al., 2012, 2017; Ribolini et al., 2018).

\section{Glacier surging and volcano-glacier interactions}

It is with some satisfaction we also reflect on two areas where Aberdeen, through Chalmers Clapperton, made a mark early on and to which the present staff continue to contribute. Chalmers published an important paper on surging glaciers and debris transport (Clapperton, 1975) and Brice Rea has continued his work on surging glaciers since coming to Aberdeen. For example, an analysis of the propagation direction and mechanics of full-depth crevasses on surging glaciers and the concomitant formation of crevasse squeeze ridges (Rea \& Evans, 2011) recalls a landform impeccably analysed by Martin Sharp in a publication (Sharp, 1985) from his Aberdeen $\mathrm{PhD}$ thesis. More recently Aberdeen has again entered the realm of volcano-glacier interactions, a subject previously investigated by Chalmers (Clapperton, 1990). Led by Matteo Spagnolo, Aberdeen is currently involved in a number of projects in this area of research (Barr et al., 2018).

\section{In summary}


Glaciology has been a mainstay of the academic profile in Aberdeen for over half of the 100-year history of the Department and during this time the research group has periodically expanded and contracted. The staff have worked across many areas of glaciology, pushing boundaries, setting benchmarks and publishing in the highest quality academic journals. It is also noteworthy that the two most influential text books in glacial geomorphology were both co-authored by Aberdeen glaciology staff: Glaciers and Landscape (1976) by David E. Sugden and Brian S. John; Glaciers and Glaciation (1998) by Douglas I. Benn and David J.A. Evans. Fieldwork has always been a core strength with the associated opportunities for enthusing undergraduate students (Figure 11). Aberdeen glaciology has trained a multitude of the next generation of scientists. It has always had a bottom-up staffing approach, appointing early career staff, providing a collaborative and supportive environment where careers can flourish. Some of the staff have moved on, some remained, others have retired and sadly one is no longer with us, but friendships and collaborations endure (Figure 12). We look positively to the future as the University of Aberdeen enters a new period of staff appointments and growth, which will hopefully be reflected in the staffing profile of the glaciology group.

\author{
Acknowledgments \\ Thanks to David Sugden, Doug Benn, Nick Spedding, Doug Mair, Alastair Dawson, Rob \\ Bingham and Tim Lane for providing photographs and images.
}

\title{
References
}

Barr, I. \& Spagnolo, M. (2013) Palaeoglacial and palaeoclimatic conditions in the NW Pacific, as revealed by a morphometric analysis of cirques upon the Kamchatka Peninsula, Geomorphology, 192, 15-29.

Barr, I. \& Spagnolo, M. (2015) Glacial cirques as palaeoenvironmental indicators: their potential and limitations, Earth-Science Reviews, 151, 48-78. 
Barr, I., Ely, J., Spagnolo, M., Clark, C., Evans, I., Pellicer, X., Pellitero, R. \& Rea, B. (2017) Climate patterns during former periods of glacier initiation in Britain and Ireland: inferences from the cirque record, Palaeogeography, Palaeoclimatology, Palaeoecology, 485, 466-475.

Barr, I., Ely, J., Spagnolo, M., Evans, I. \& Tomkins, M. D. (in press) The dynamics of mountain erosion: cirque growth slows as landscapes age, Earth Surface Processes and Landforms.

Bartholomew, I., Nienow, P., Mair, D., Hubbard, A., King, M. A. \& Sole, A. (2010) Seasonal evolution of subglacial drainage and acceleration in a Greenland outlet glacier, Nature Geoscience, 3, 408-411.

Bartholomew, I. D., Nienow, P., Sole, A., Mair, D., Cowton, T., King, M. A. \& Palmer, S. (2011a) Seasonal variations in Greenland Ice Sheet motion: Inland extent and behaviour at higher elevations, Earth and Planetary Science Letters, 307, 271278.

Bartholomew, I., Nienow, P., Sole, A., Mair, D., Cowton, T., Palmer, S. \& Wadham, J. (2011b) Supraglacial forcing of subglacial drainage in the ablation zone of the Greenland ice sheet, Geophysical Research Letters, 38, art. no. L08502.

Bartholomew, I., Nienow, P., Sole, A., Mair, D., Cowton, T. \& King, M. A. (2012) Short-term variability in Greenland Ice Sheet motion forced by time-varying meltwater drainage: Implications for the relationship between subglacial drainage system behavior and ice velocity, Journal of Geophysical Research: Earth Surface, 117, art. no. F03002.

Benn, D. I. (1994a) Fluted moraine formation and till genesis below a temperate valley glacier: Slettmarkbreen, Jotunheimen, southern Norway, Sedimentology, 41, 279-292.

Benn, D. I. (1994b) Fabric shape and the interpretation of sedimentary fabric data, Journal of Sedimentary Research A: Sedimentary Petrology \& Processes, A64, 910-915.

Benn, D. I. \& Ballantyne, C. K. (1994) Reconstructing the transport history of glacigenic sediments: a new approach based on the co-variance of clast form indices, Sedimentary Geology, 91, 215-227.

Benn, D. I. \& Evans, D. J. A. (1996) The interpretation and classification of subglacially-deformed materials, Quaternary Science Reviews, 15, 23-52.

Benn, D. I. \& Evans, D. J. A. (1998) Glaciers and Glaciation (London: Routledge). 
Benn, D. I. \& Gemmell, A. M. D. (1997) Calculating equilibrium-line altitudes of former glaciers by the balance ratio method: a new computer spreadsheet, Glacial Geology and Geomorphology.

Benn, D. I. \& Owen, L. A. (1998) The role of the Indian summer monsoon and the midlatitude westerlies in Himalayan glaciation: review and speculative discussion, Journal of the Geological Society, 155, 353-363.

Bingham, R. G. \& Siegert, M. J. (2009) Quantifying subglacial bed roughness in Antarctica: implications for ice-sheet dynamics and history, Quaternary Science Reviews, 28, 223-236.

Bingham, R. G., Ferraccioli, F., King, E. C., Larter, R. D., Pritchard, H. D., Smith, A. M. \& Vaughan, D. G. (2012) Inland thinning of West Antarctic Ice Sheet steered along subglacial rifts, Nature, 487, 468-471.

Bingham, R. G., Vaughan, D. G., King, E. C., Davies, D., Cornford, S. L., Smith, A. M., Arthern, R. J., Brisbourne, A. M., De Rydt, J., Graham, A. G. C., Spagnolo, M., Marsh, O. J. \& Shean, D. E. (2017) Diverse landscapes beneath Pine Island Glacier influence ice flow, Nature Communications, 8, 16-18.

Bremner, A. (1934) The glaciation of Abernethy Forest, Transactions of the Edinburgh Geological Society, 13, pp. 1-16.

Bremner, A. (1939) The late-glacial geology of the Tay Basin from Pass of Birnam to Grantully and Pitlochry, Transactions of the Edinburgh Geological Society, 13, pp. 473-474.

Chandler, D. M., Wadham, J. L., Lis, G. P., Cowton, T., Sole, A., Bartholomew, I., Telling, J. Nienow, P., Bagshaw, E. B., Mair, D., Vinen, S. \& Hubbard, A. (2013) Evolution of the subglacial drainage system beneath the Greenland Ice Sheet revealed by tracers, Nature Geoscience, 6, 195-198.

Clapperton C. M. (1975) The debris content of surging glaciers in Svalbard and Iceland, Journal of Glaciology, 14, 395-406.

Clapperton, C. M. (1990) Glacial and volcanic geomorphology of the ChimborazoCarihuairazo Massif, Ecuadorian Andes, Transactions of the Royal Society of Edinburgh: Earth Sciences, 81, 91-116.

Clapperton, C. M. (1993) Quaternary Geology and Geomorphology of South America (Amsterdam: Elsevier Science).

Clapperton, C. M. \& Gemmell, A. M. D. (1998) Windy Hills SSSI, Aberdeenshire: Site Survey and Management Phase 1 (Edinburgh: Scottish Natural Heritage). 
Clapperton, C. M. \& Sugden, D. E. (1982) Late quaternary glacial history of George VI Sound area, West Antarctica, Quaternary Research, 18, 243-267.

Clapperton, C. M., Clayton, J. D., Benn, D. I., Marden, C. J. \& Argollo, J. (1997) Late Quaternary glacier advances and palaeolake highstands in the Bolivian Altiplano, Quaternary International, 38, 49-59.

Costa, P. J. M., Andrade, C., Dawson, A. G., Mahaney, W. C., Freitas, M. C., Paris, R. \& Taborda, R. (2012) Microtextural characteristics of quartz grains transported and deposited by tsunamis and storms, Sedimentary Geology, 275-276, 55-69.

Davies, D., Bingham, R. G., Graham, A. G. C., Spagnolo, M., Dutrieux, P., Vaugan, D. J., Jenkins, A. \& Nitsche, F. O. (2017) High-resolution sub-ice-shelf seafloor records of $20^{\text {th }}$-century ungrounding and retreat of Pine Island Glacier, West Antarctica, Journal of Geophysical Research - Earth Surface, 122, 1698-1714.

Davies, D., Bingham, R. G., King, E. C., Smith, A. M., Brisbourne, A. M., Spagnolo, M., Graham, A. G. C., Hogg, A. E. \& Vaughan, D. G. (2018) How dynamic are ice-stream beds?, The Cryosphere, 12, 1615-1628.

Dawson, A. G. (2009) So Foul and Fair a Day: a History of Scotland's Weather and Climate (Edinburgh: Birlinn).

Dawson, A.G. \& Stewart, I. (2007) Tsunami deposits in the geological record, Sedimentary Geology, 200 (3-4), 166-183.

Dawson, A. G., Hickey, K., Mayewski, P. A. \& Nesje, A. (2007) Greenland (GISP2) ice core and historical indicators of complex North Atlantic climate changes during the fourteenth century, Holocene, 17, 427-434.

Dugmore, A. J., Borthwick, D. M., Church, M. J., Dawson, A., Edwards, K. J., Keller, C., Mayewski, P., McGovern, T. H., Mairs, K.-A. \& Sveinbjarnardóttir, G. (2007) The role of climate in settlement and landscape change in the North Atlantic Islands: An assessment of cumulative deviations in high-resolution proxy climate records, Human Ecology, 35, 169-178.

Ely, J. C., Graham, C., Barr, I. D., Rea, B. R., Spagnolo, M. \& Evans, J. (2017) Using UAV acquired photography and structure from motion techniques for studying glacier landforms: application to the glacial flutes at Isfallsglaciären, Earth Surface Processes and Landforms, 42, 877-888.

Evans, D. J. A., Clark, C. D. \& Rea, B. R. (2008) Palaeo ice stream activity in the southwest Laurentide Ice Sheet, and associated styles of ice-marginal deposition, Journal of Quaternary Science, 249-272. 
Federici, P. R., Granger, D., Ribolini, A., Spagnolo, M., Pappalardo, M. \& Cyr, A. (2012) Last Glacial Maximum and the Gschnitz stadial in the Maritime Alps according to ${ }^{10} \mathrm{Be}$ cosmogenic dating, Boreas, 41, 277-291.

Federici, P. R., Ribolini, A. \& Spagnolo, M. (2017) Glacial history of the Maritime Alps from the Last Glacial Maximum to the Little Ice Age. In: Hughes, P. D. \& Woodward, J. C. (eds), Quaternary Glaciation in the Mediterranean Mountains. Geological Society, London, Special Publications, 433, 137-159.

Fretwell, P., Pritchard, H. D., Vaughan, D. G., Bamber, J. L., Barrand, N. E., Bell, R., Bianchi, C., Bingham, R. G., Blankenship, D. D., Casassa, G., Catania, G., Callens, D., Conway, H., Cook, A. J., Corr, H. F. J., Damaske, D., Damm, V., Ferraccioli, F., Forsberg, R., Fujita, S., Gim, Y., Gogineni, P., Griggs, J. A., Hindmarsh, R. C. A., Holmlund, P., Holt, J. W., Jacobel, R. W., Jenkins, A., Jokat, W., Jordan, T., King, E. C., Kohler, J., Krabill, W., Riger-Kusk, M., Langley, K. A., Leitchenkov, G., Leuschen, C., Luyendyk, B. P., Matsuoka, K., Mouginot, J., Nitsche, F. O., Nogi, Y., Nost, O. A., Popov, S. V., Rignot, E., Rippin, D. M., Rivera, A., Roberts, J., Ross, N., Siegert, M. J., Smith, A. M., Steinhage, D., Studinger, M., Sun, B., Tinto, B. K., Welch, B. C., Wilson, D., Young, D. A., Xiangbin, C. \& Zirizzotti, A. (2013) Bedmap2: improved ice bed, surface and thickness datasets for Antarctica, The Cryosphere, 7, 375-393.

Gemmell, A. M. D. (1988) Zeroing of the TL signal in sediment undergoing fluvioglacial transport. An example from Austerdalen, Western Norway, Quaternary Science Reviews, 7, 339-345.

Gemmell, A. M. D. (1994) Thermoluminescence in suspended sediment of glacier meltwater streams, Journal of Glaciology, 40, 158-166.

Gemmell, A. M. D. (1997) Fluctuations in the thermoluminescence signal of suspended sediment in an alpine glacial meltwater stream, Quaternary Science Reviews, 16, 281-290.

Gemmell, A. M. D. (1999) IRSL from fine-grained glacifluvial sediment, Quaternary Geochronology (Quaternary Science Reviews), 18, 207-215.

Gemmell, A. M. D. \& Stove, G. C. (1999) Windy Hill SSSI, Aberdeenshire: Site Survey and Management Phase 2 (Edinburgh: Scottish Natural Heritage).

Gemmell, A. M. D., Murray, A. S. \& Connell, E. R. (2007) Devensian glacial events in Buchan (NE Scotland): a progress report on new OSL dates and their implications, Quaternary Geochronology, 2, 237-242. 
Gemmell, A. M. D. \& Spötl, C. (2009) Attempts to date the Hötting Breccia near Innsbruck (Austria), a classical Quaternary site in the Alps, by opticallystimulated luminescence, Austrian Journal of Earth Sciences, 102, 50-61.

Jamieson, S. R., Stokes, C. R., Livingstone, S. J., Vieli, A., O’ Cofaigh, C., Hillenbrand C.-D. \& Spagnolo, M. (2016) Subglacial processes on an Antarctic Ice Stream bed 2: Can modelled ice dynamics explain the morphology of mega-scale glacial lineations?, Journal of Glaciology, 62, 232, 285-298.

Kesel, R. H. \& Gemmell, A. M. D. (1981) The 'Pliocene' Gravels of Buchan: a reappraisal, Scottish Journal of Geology, 17, 185-203.

Kirkbride, M. \& Spedding, N. (1996) The influence of englacial drainage on sedimenttransport pathways and till texture of temperate valley glaciers, Annals of Glaciology, 22, 160-166.

Kortekaas, S. \& Dawson, A. G. (2007) Distinguishing tsunami and storm deposits: An example from Martinhal, SW Portugal, Sedimentary Geology, 200, 208-221.

Livingstone, S. J., Stokes, C. R., O’ Cofaigh, C., Hillenbrand C.-D., Vieli, A., Jamieson, S. R., Spagnolo, M. \& Dowdeswell, J. A. (2016) Subglacial processes on an Antarctic ice stream bed 1: sediment transport and bedform genesis inferred from marine geophysical data, Journal of Glaciology, 62, 232, 270-284.

Mair, D., Willis, I., Fischer, U. H., Hubbard, B., Nienow, P. \& Hubbard, A. (2004) Hydrological controls on patterns of surface, internal and basal motion during three "spring events": Haut Glacier d'Arolla, Switzerland, Journal of Glaciology, $49,555-567$.

Maizels, J. (1979) Proglacial aggradation and changes in braided channel patterns during a period of glacier advance: an alpine example, Geografiska Annaler: Series A, Physical Geography, 61, 87-101.

Maizels, J. (1989a) Sedimentology, paleoflow dynamics and flood history of Jökulhlaup deposits: paleohydrology of Holocene sediment sequences in southern Iceland sandur deposits, Journal of Sedimentary Petrology, 59, 204-223.

Maizels, J. K. (1989b) Differentiation of late pleistocene terrace outwash deposits using geomorphic criteria: Tekapo valley, South Island, New Zealand, New Zealand Journal of Geology and Geophysics, 32, 225-241.

Maizels, J. (1990) Raised channel systems as indicators of palaeohydrologic change: a case study from Oman, Palaeogeography, Palaeoclimatology, Palaeoecology, $76,241-277$. 
Maizels, J. (1992) Boulder ring structures produced during Jokulhlaup flows: origin and hydraulic significance, Geografiska Annaler, 74A, 21-33.

Maizels, J. (1993) Lithofacies variations within sandur deposits: the role of runoff regime, flow dynamics and sediment supply characteristics, Sedimentary Geology, 85, 299-325.

Maizels, J. (1997) Jokulhlaup deposits in proglacial areas. Quaternary Science Reviews, $16,793-819$.

Moran, K., Backman, J., Brinkhuis, H., Clemens, S. C., Cronin, T., Dickens, G.R., Eynaud, F., Gattacceca, J., Jakobsson, M., Jordan, R. W., Kaminski, M., King, J., Koc, N., Krylov, A., Martinez, N., Matthiessen, J., McInroy, D., Moore, T. C., Onodera, J., O'Regan, M., Palike, H., Rea, B. R., Rio, D., Sakamoto, T., Smith, D. C., Stein, R., St John, K., Suto, I., Suzuki, N., Takahashi, K., Watanabe, M., Yamamoto, M., Farrell, J., Frank, M., Kubik, P., Jokat, W. \& Kristoffersen, Y. (2006) The Cenozoic palaeoenvironment of the Arctic Ocean, Nature, 441, 601-605.

Pellitero, R., Rea, B. R., Spagnolo, M., Bakke, J., Hughes, P., Ivy-Ochs, S., Lukas, S. \& Ribolini, A. (2015) A GIS tool for automatic calculation of glacier equilibriumline altitudes, Computers \& Geosciences, 82, 55-62.

Pellitero, R. Rea, B. R., Spagnolo, M., Bakke, J., Ivy-Ochs, S., Frew, C., Hughes, P., Ribolini, A., Lukas, S. \& Renssen, H. (2016) GlaRe, a GIS tool to reconstruct the 3D surface of palaeoglaciers, Computers and Geoscience, 94, 77-85.

Rea, B. R. and Evans, D. J. A. (2007) Quantifying climate and glacier mass balance in North Norway during the Younger Dryas. Palaeogeography, Palaeoclimatology, Palaeoecology, 246, 307-330.

Rea B. R. (2009) Defining modern day Area-Altitude-Balance-Ratios (AABRs) and their use in glacier-climate reconstructions, Quaternary Science Reviews, 28, $237-248$.

Rea, B. R. \& Evans, D. J. A. (2011) An assessment of surge-induced crevassing and the formation of crevasse squeeze ridges, Journal of Geophysical Research, 116, F04005.

Rea, B. R. \& Gemmell, A. M. D. (2009) Scottish Landform Example 40: The Buchan Gravels Formation; a remnant deposit of a palaeo-landscape, Scottish Geographical Journal, 125, 182. 
Ribolini, A., Bini, M., Isola, I., Spagnolo, M., Zanchetta, G., Pellitero, R., Mechernich, S., Gromig, R., Dunai, T., Wagner, B. \& Milevski, I. (2018) An Oldest Dryas glacier expansion on Mount Pelister (Former Yugoslavian Republic of Macedonia) according to ${ }^{10} \mathrm{Be}$ cosmogenic dating, Journal of the Geological Society, 175, 100-110.

Roberts, D. H., Rea, B. R., Lane, T. P., Schnabel, C., Rodés, A. (2013) New constraints on Greenland ice sheet dynamics during the LGM: evidence from the Uummannaq ice stream system, Journal of Geophysical Research, doi: 10.1002/jgrf.20032

Ross, N., Bingham, R. G., Corr, H. F .J., Ferraccioli, F., Jordan, T. A., Le Brocq, A., Rippin, D. M., Young, D., Blankenship, D. D. \& Siegert, M. J. (2012) Steep reverse bed slope at the grounding line of the Weddell Sea sector in West Antarctica, Nature Geoscience, 5, 393-396.

Sharp, M. (1985) “Crevasse-fill” ridges - a landform type characteristic of surging glaciers?, Geografiska Annaler, 67A, 213-220.

Sluijs, Appy, Schouten, Stefan, Pagani, Mark, Woltering, Martijn, Brinkhuis, Henk, Sinninghe Damsté, Jaap S., Dickens, Gerald R., Huber, Matthew, Reichart, Gert-Jan, Stein, Rüdiger, Matthiessen, J., Lourens, L. J., Pedenchouk, N., Backman, J., Moran, K., Clemens, S., Eynaud, F., Gattacceca, J., Jakobsson, M., Jordan, R., Kaminski, M., King, J., Koc, N., Martinez, N. C., McInroy, D., Moore, T. C. Jr., O’Regan, M., Pälike, H., Rea, B., Rio, D., Sakamoto, T., Smith, D. C., St. John, K. E. K., Suto, I., Suzuki, N., Watanabe, M. \& Yamamoto, M. (2006) Subtropical Arctic Ocean temperatures during the Palaeocene/Eocene thermal maximum, Nature, 441, 610-613.

Smith, A. M., Jordan, T. A., Ferraccioli, F. \& Bingham, R. G. (2013) Influence of subglacial conditions on ice stream dynamics: Seismic and potential field data from Pine Island Glacier, West Antarctica, Journal of Geophysical Research: Solid Earth, 118, 1471-1482.

Sole, A. J., Mair, D. W. F., Nienow, P. W., Bartholomew, I. D., King, M. A., Burke, M. J. \& Joughin, I. (2011) Seasonal speedup of a Greenland marine-terminating outlet glacier forced by surface melt-induced changes in subglacial hydrology, Journal of Geophysical Research: Earth Surface, 116, art. no. F03014. 
Sole, A., Nienow, P., Bartholomew, I., Mair, D., Cowton, T., Tedstone, A. \& King, M. A. (2013) Winter motion mediates dynamic response of the Greenland Ice Sheet to warmer summers, Geophysical Research Letters, 40, 3940-3944.

Spagnolo, M. \& Ribolini, A. (submitted) Glacier extent and climate in the Maritime Alps during the Younger Dryas, Palaeogeography, Palaeoclimatology, Palaeoecology.

Spagnolo, M., Clark, C. D. \& Hughes, A. L. C. (2012) Drumlin relief, Geomorphology, 153-154, 179-191.

Spagnolo, M., Clark, C. D., Ely, J. C., Stokes, C. R., Anderson, J. B., Andreassen, K., Graham, A. G. C. \& King, E. C. (2014) Size, shape and spatial arrangement of mega-scale glacial lineations, Earth Surface Processes and Landforms, 39, $1432-1448$.

Spagnolo, M., Phillips, E., Piotrowski, J., Rea, B. R., Clark, C. D., Stokes, C. R., Carr, S., Ely, J. C., Ribolini, A., Wysota, W. \& Szuman, I. (2016) Ice stream motion facilitated by a shallow-deforming and accreting bed, Nature Communications, 7, 10723, 1-11.

Spagnolo, M., Bartholomaus, T. C., Clark, C. D., Stokes, C. R., Atkinson, N., Dowdeswell, J. A., Ely, J. C., Graham, A., Hogan, K. A., King, Larter, R. D. E., Livingstone, S. J. \& Pritchard. H. D. (2017a) The periodic topography of ice stream beds: insights from the Fourier spectra of mega-scale glacial lineations, Journal of Geophysical Research - Earth Surface, 122, 1355-1373.

Spagnolo, M., Pellitero, R., Barr, I. D., Ely, J. C., Pellicer, X. M. \& Rea, B. R. (2017) ACME, a GIS tool for Automated Cirque Metric Extraction, Geomorphology, 278, 280-286.

Spedding, N. (1997) On growth and form in geomorphology, Earth Surface Processes and Landforms, 22, 261-265.

Spedding, N. (1999) Schrödinger's cat among the pigeons? Transactions of the Institute of British Geographers, 24, 231-235.

Spedding, N. \& Evans, D. J. A. (2002) Sediments and landforms at Kvíárjökull, southeast Iceland: a reappraisal of the glaciated valley landsystem, Sedimentary Geology, 149, 21-42.

Sugden, D. E. (1969a) Preliminary report of the Aberdeen university west Greenland expedition 1968, Scottish Geographical Magazine, 85, 105-108. 
Sugden, D. E. (1969b) The age and form of corries in the Cairngorms, Scottish Geographical Magazine, 85, 34-46.

Sugden, D. E. \& Clapperton, C. M. (1980) West Antarctic ice sheet fluctuations in the Antarctic Peninsula area, Nature, 286, 378-381.

Sugden, D. E., Clapperton, C. M. (1981) Ice-shelf moraine, George VI Sound, Antarctica, Annals of Glaciology, 2, 131-141.

Sugden, D. E. \& John, B. S. (1976) Glaciers and landscape: a geomorphological approach (London: Edward Arnold).

Sugden, D. E. \& Watts, S. H. (1977) Tors, felsenmeer, and glaciation in Northern Cumberland Peninsula, Baffin Island, Canadian Journal of Earth Sciences, 14, $2817-2823$.

Sugden, D. E. (2019) Chalmers Moyes Clapperton-an obituary. Scottish Geographical Journal, 135, 150-151.

Swift, D. A., Nienow, P. W., Spedding, N. \& Hoey, T. B. (2002) Geomorphic implications of subglacial drainage configuration: Rates of basal sediment evacuation controlled by seasonal drainage system evolution, Sedimentary Geology, 149, 5-19.

Tremblay, M., Shuster, D., Spagnolo, M., Renssen, H. \& Ribolini, A. (2019) Temperatures recorded by cosmogenic noble gases since the last glacial maximum in the Maritime Alps, Quaternary Research, 91, 829-847. 

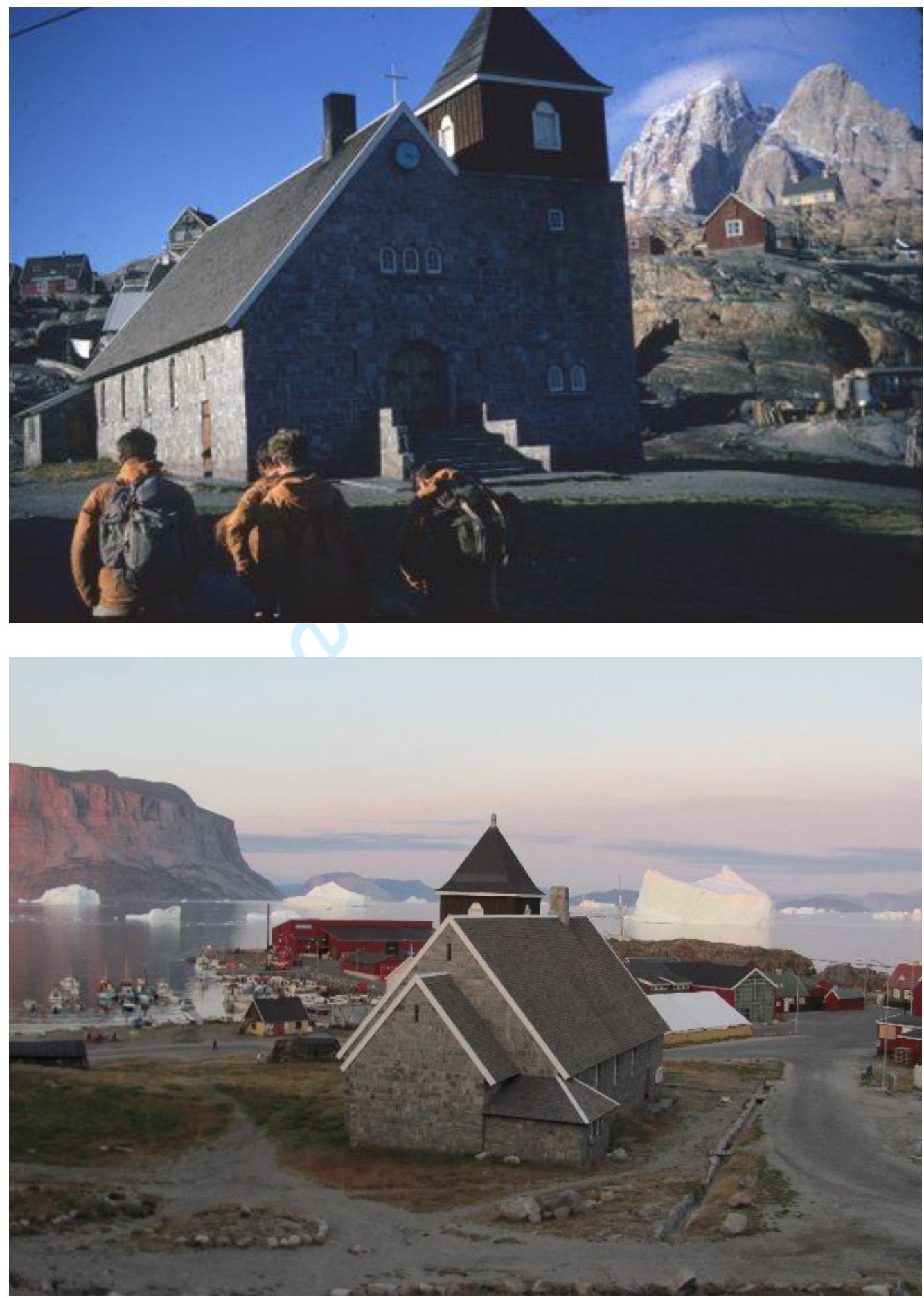

Figure 1. The church in Uummannaq as seen by Al Gemmell on Aberdeen University Expedition to Greenland in 1968 (top) and the same church, looking down the hill, as seen when Aberdeen (Brice Rea) returned in 2008, forty years later (bottom - photo from Tim Lane). 

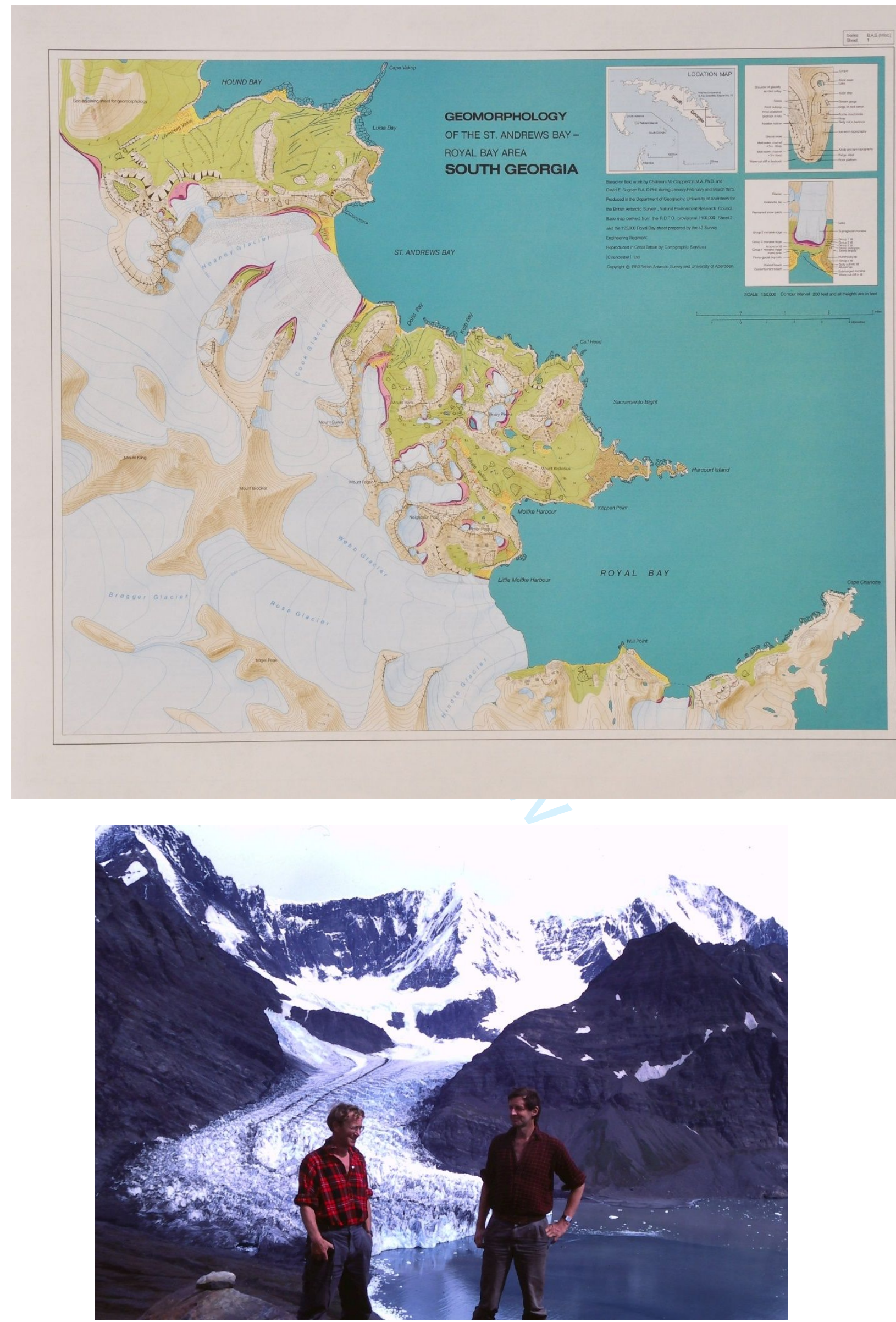
Figure 2. Geomorphological map of the St Andrews Bay - Royal Bay area South Georgia (top) and Chalmers Clapperton (left) and David Sugden (right) with Harker Glacier in the background (bottom) (photo from David Sugden). 


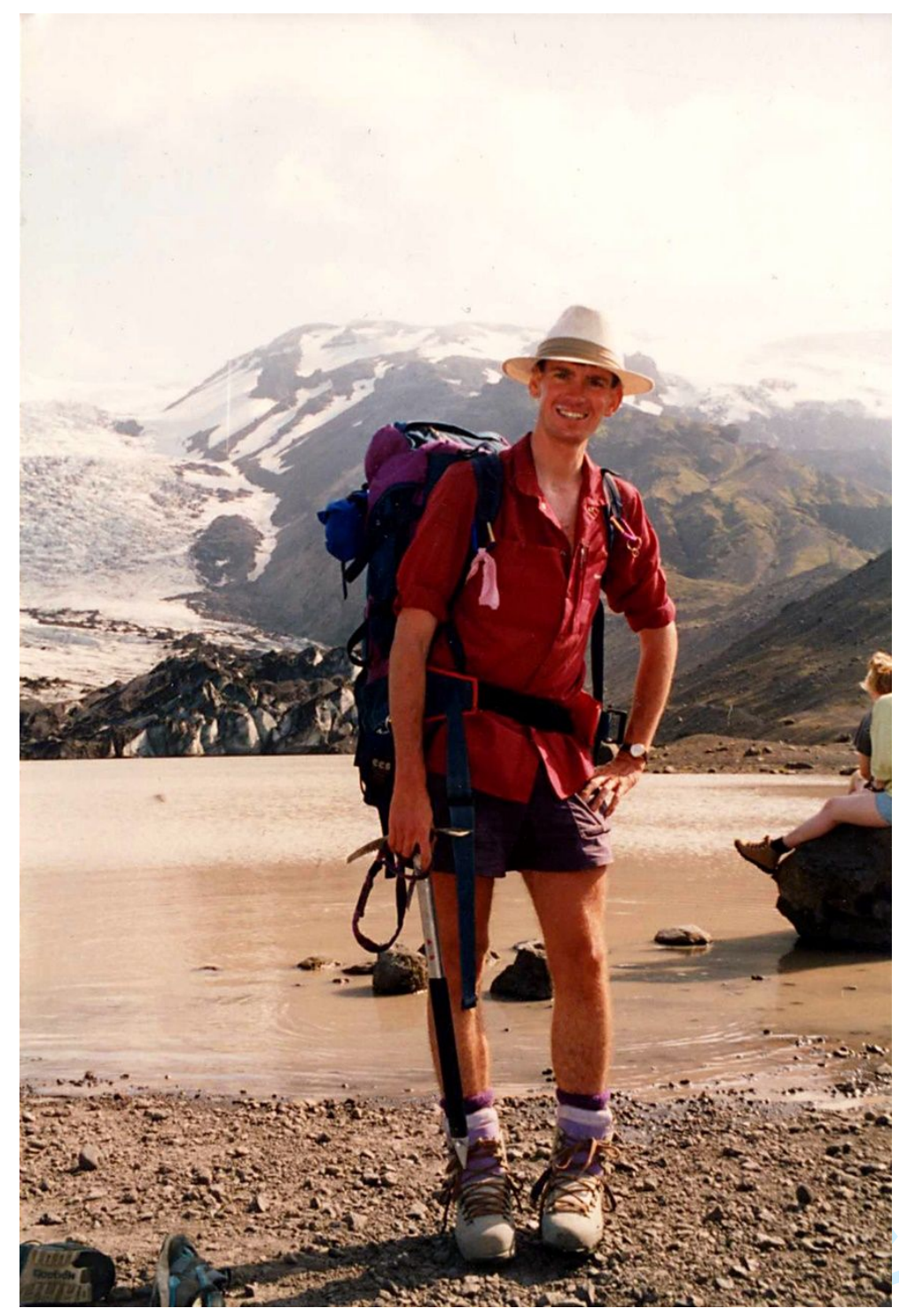

Figure 3. Nick Spedding at Gígjökull, Iceland, undertaking research on the links between subglacial overdeepenings and sediment transport, evidenced here by the proglacial lake, and the large lateral moraine ramparts, just visible on the right (photo from Nick Spedding). 


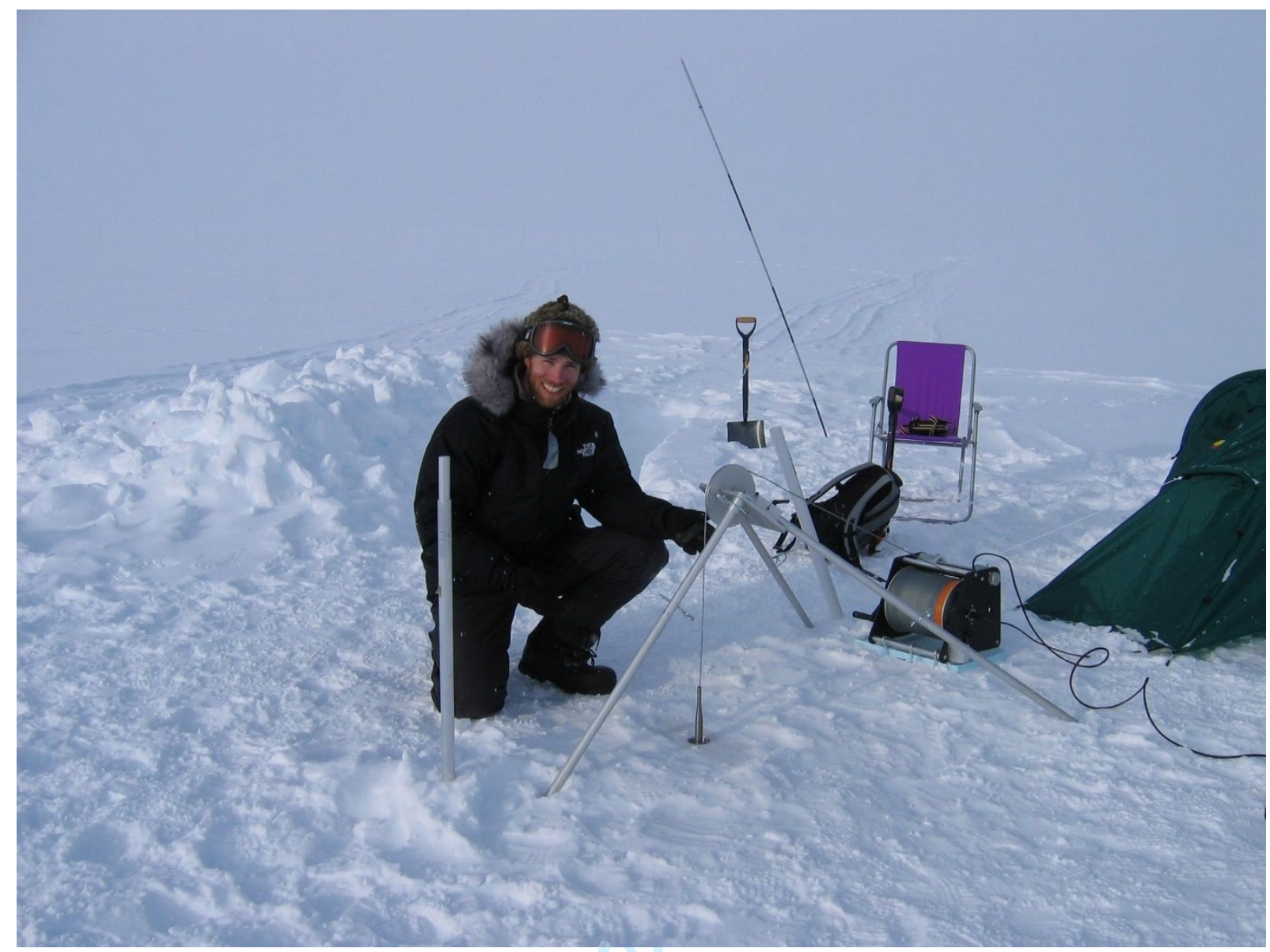

Figure 4. Doug Mair in the interior of the Greenland Ice Sheet where he spent several months in 2004-06 working to understand the effect that surface melting, and its subsequent refreezing, has had on measurements of ice sheet mass and elevation change. Here using a Neutron probe to measure snow and ice density in a borehole (photo from Doug Mair). 


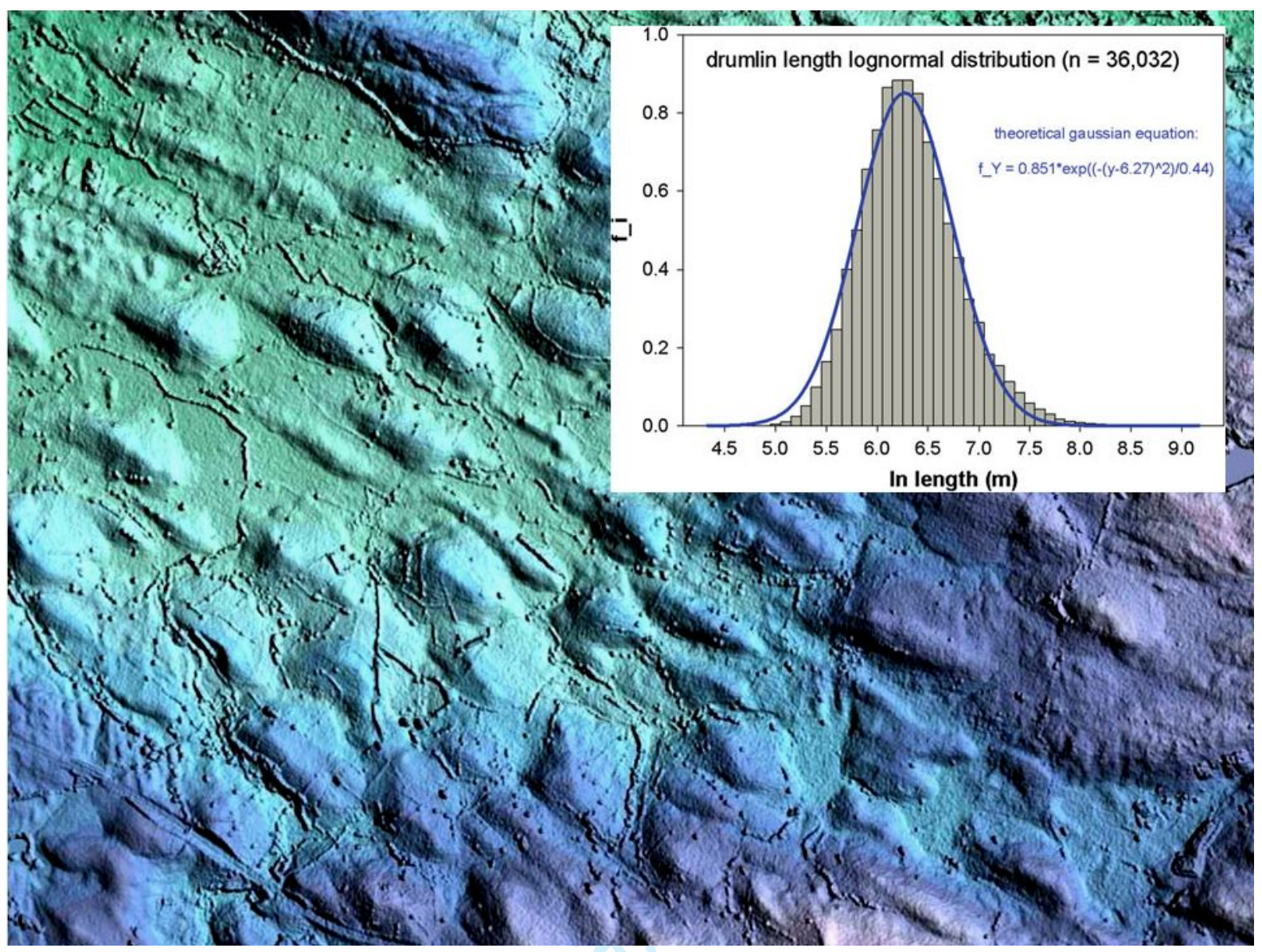

Figure 5. A high-resolution LiDar image of drumlins in the Eden Valley and inset showing morphometric analysis of a large UK-wide dataset. 


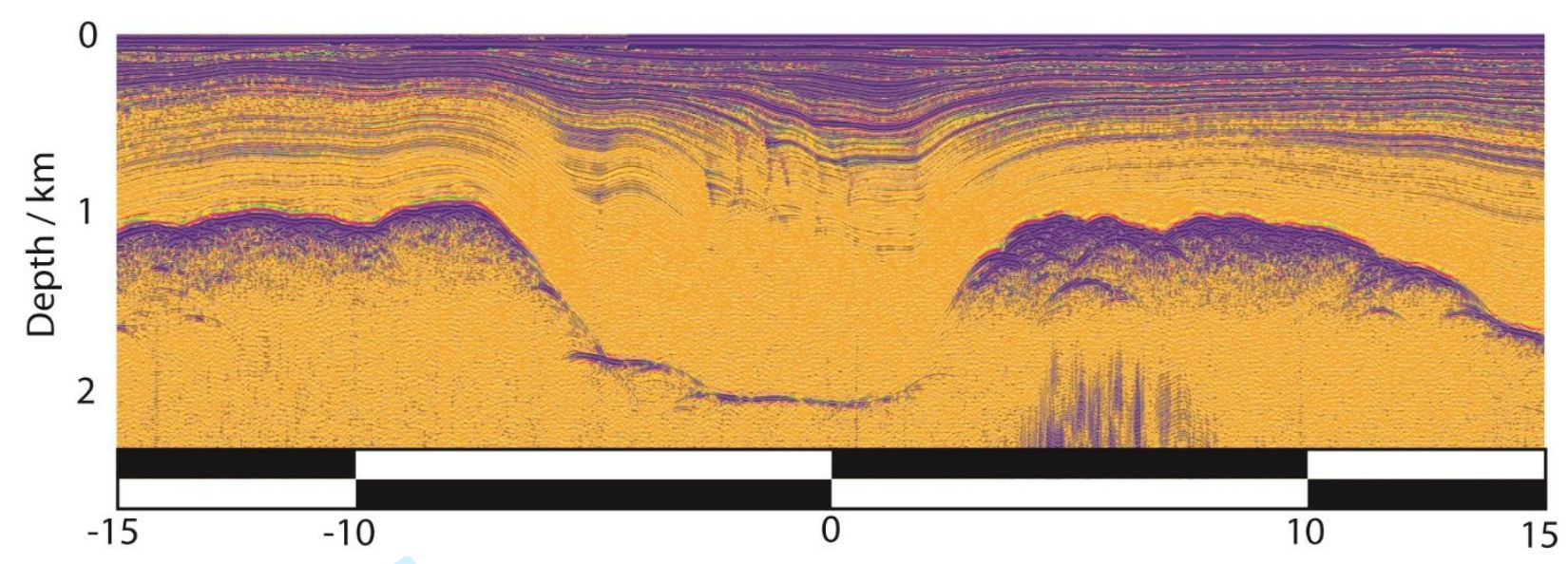

Figure 6. A 30-km GPR profile acquired across Antarctica's Ferrigno Rift by Rob Bingham in the austral season 2009-10. This feature guides ongoing ocean-forced thinning in this part of Antarctica, and it may have provided a marine link between the Bellingshausen and Weddell Seas when West Antarctica was last ice-free (image from Rob Bingham). 


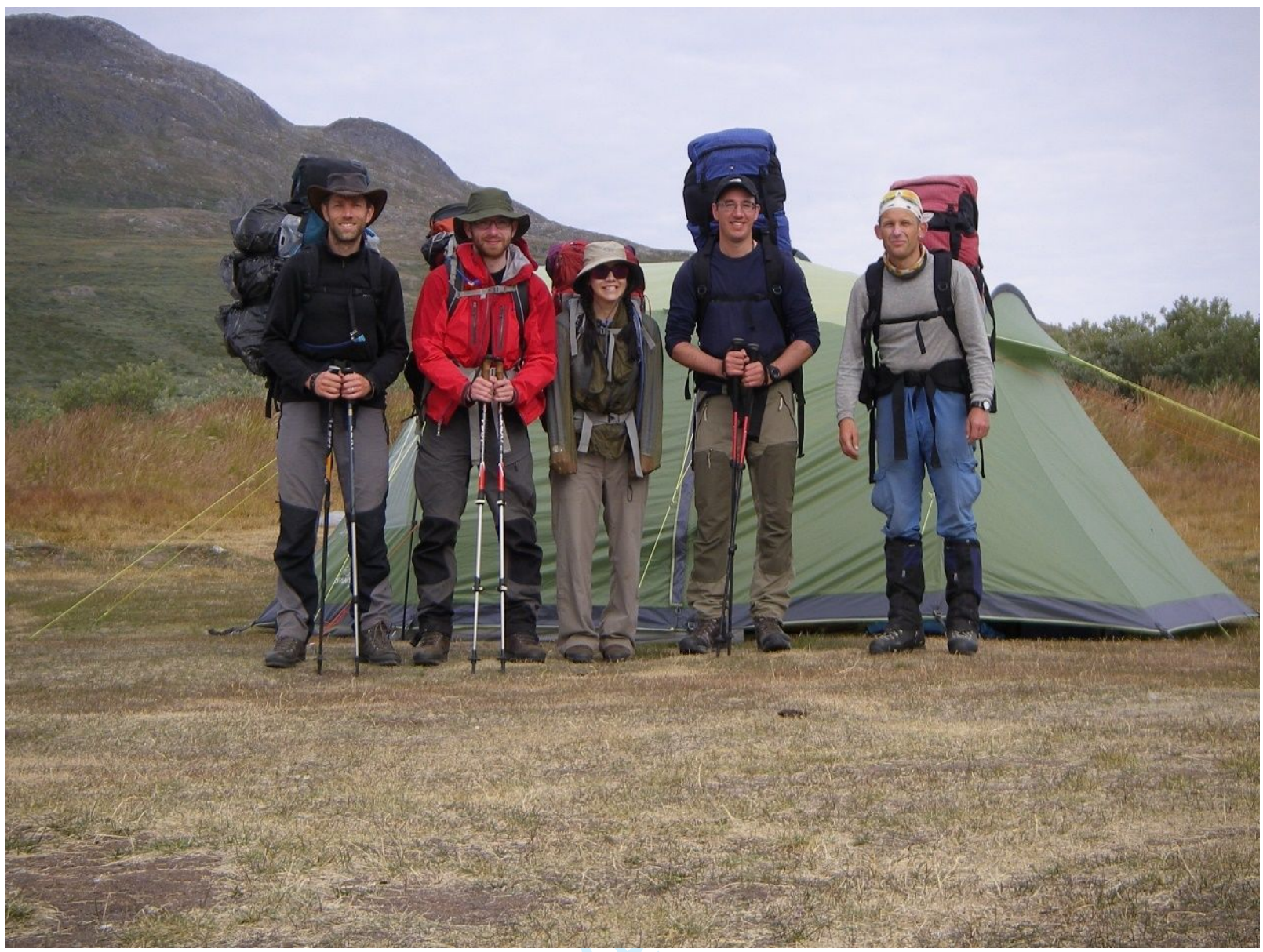

Figure 7. The Aberdeen team in Greenland in 2015, leaving basecamp at Sandnes for Austmannadalen. From left to right: Doug Mair, James Lea, Danni Pearce, Ed Schofield and Brice Rea. 


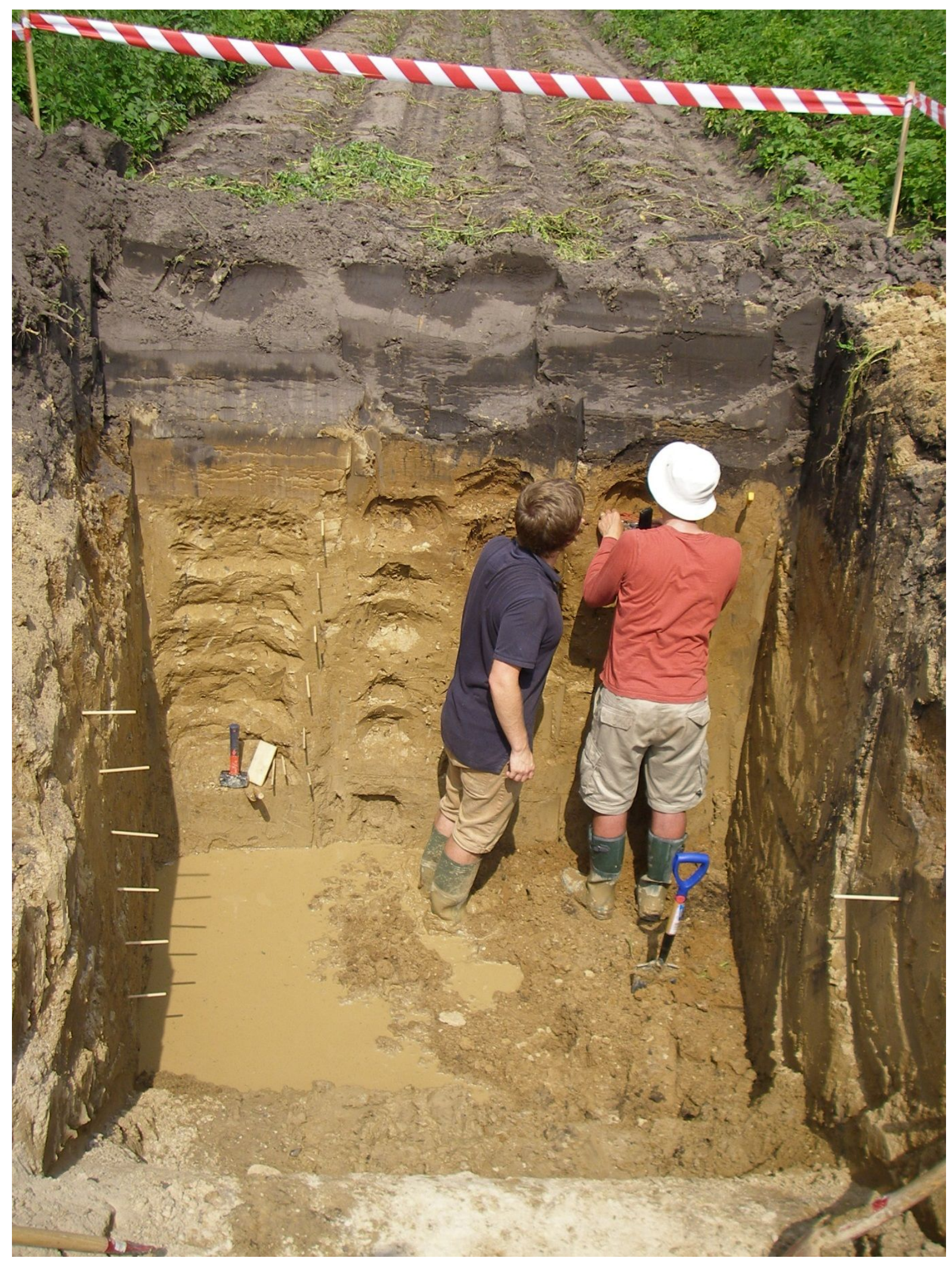


Figure 8. Detailed investigations of mega scale glacial lineations, formed at the bed of the Odra palaeo-ice stream, in the Wielkopolska Lowland Poland. On the left Jeremy Ely (University of Sheffield) and Matteo Spagnolo (Aberdeen). 


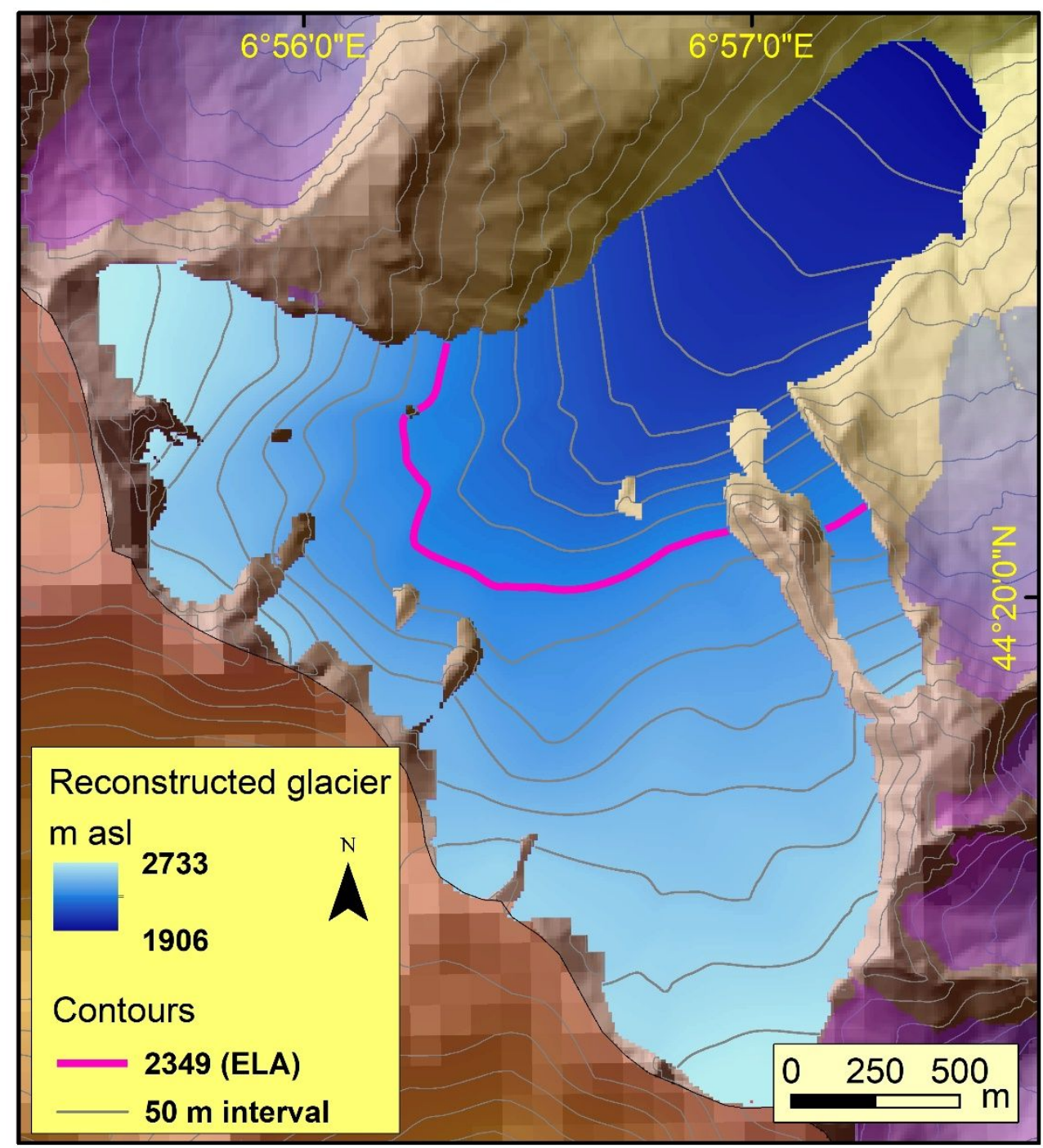

Figure 9. An automated palaeoglacier reconstruction and calculated ELA, generated for a frontal moraine dated to the Younger Dryas in the Maritime Alps. This was generated using GIS tools (GlaRe) developed in Aberdeen. 

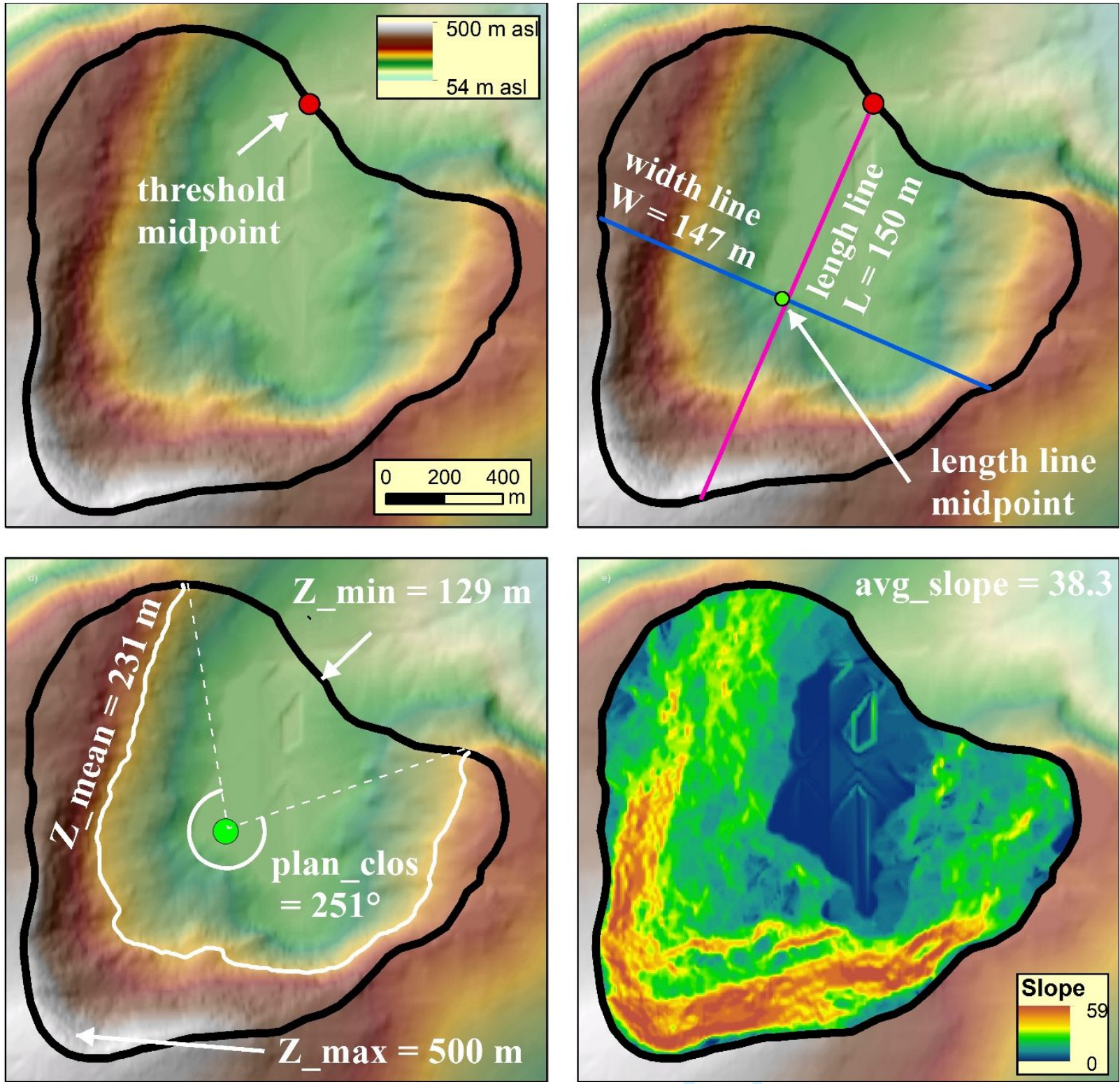

Figure 10. An example the metrics, automatically extracted from a digital terrain model, generated by ACME, a GIS tool developed in Aberdeen to analyse glacial cirque metrics. 


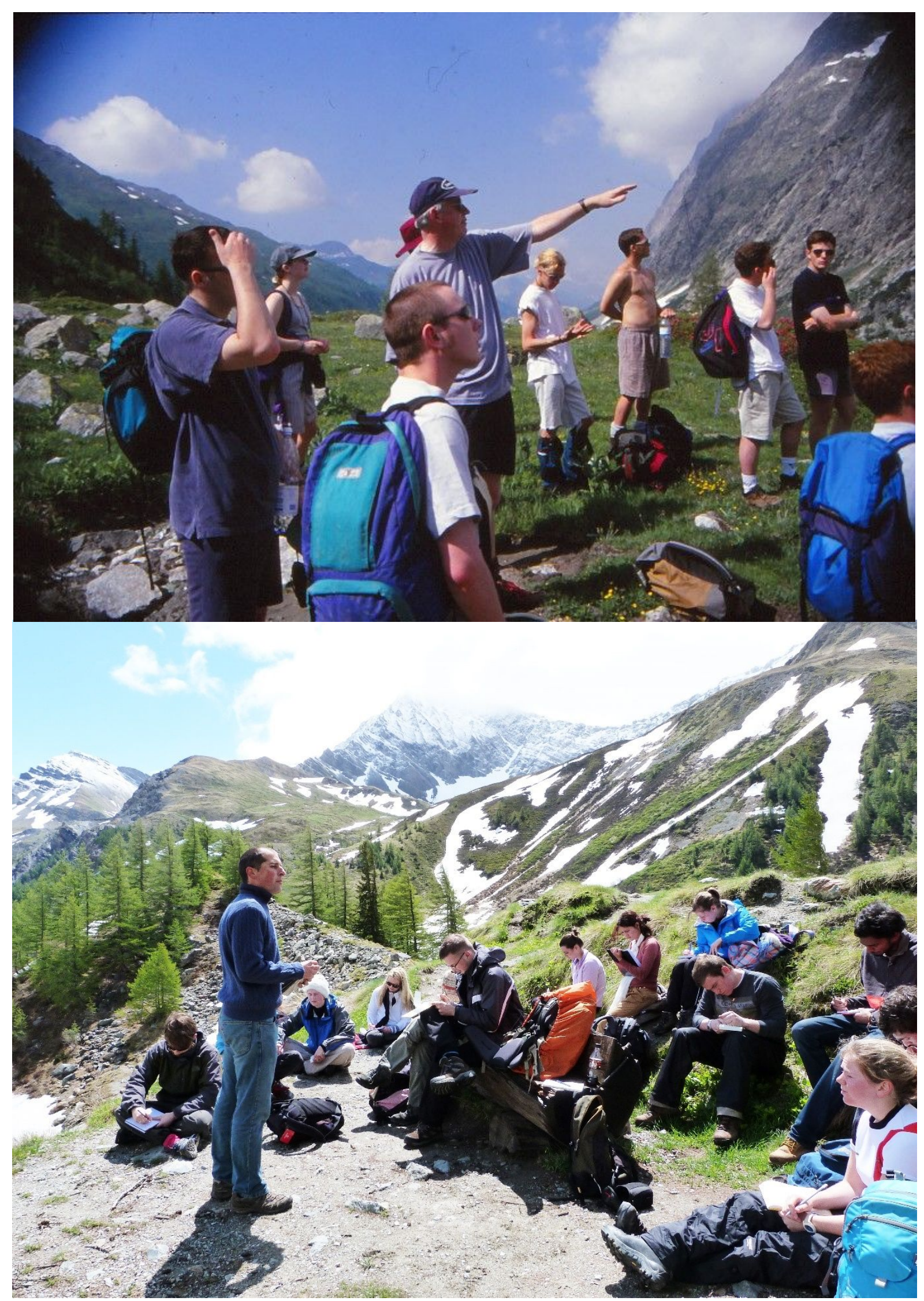


Figure 11. Students being taught on the long-running Montane Environments course by Al Gemmell in 1997 (top - photo from Nick Spedding) and by Matteo Spagnolo in 2014. 

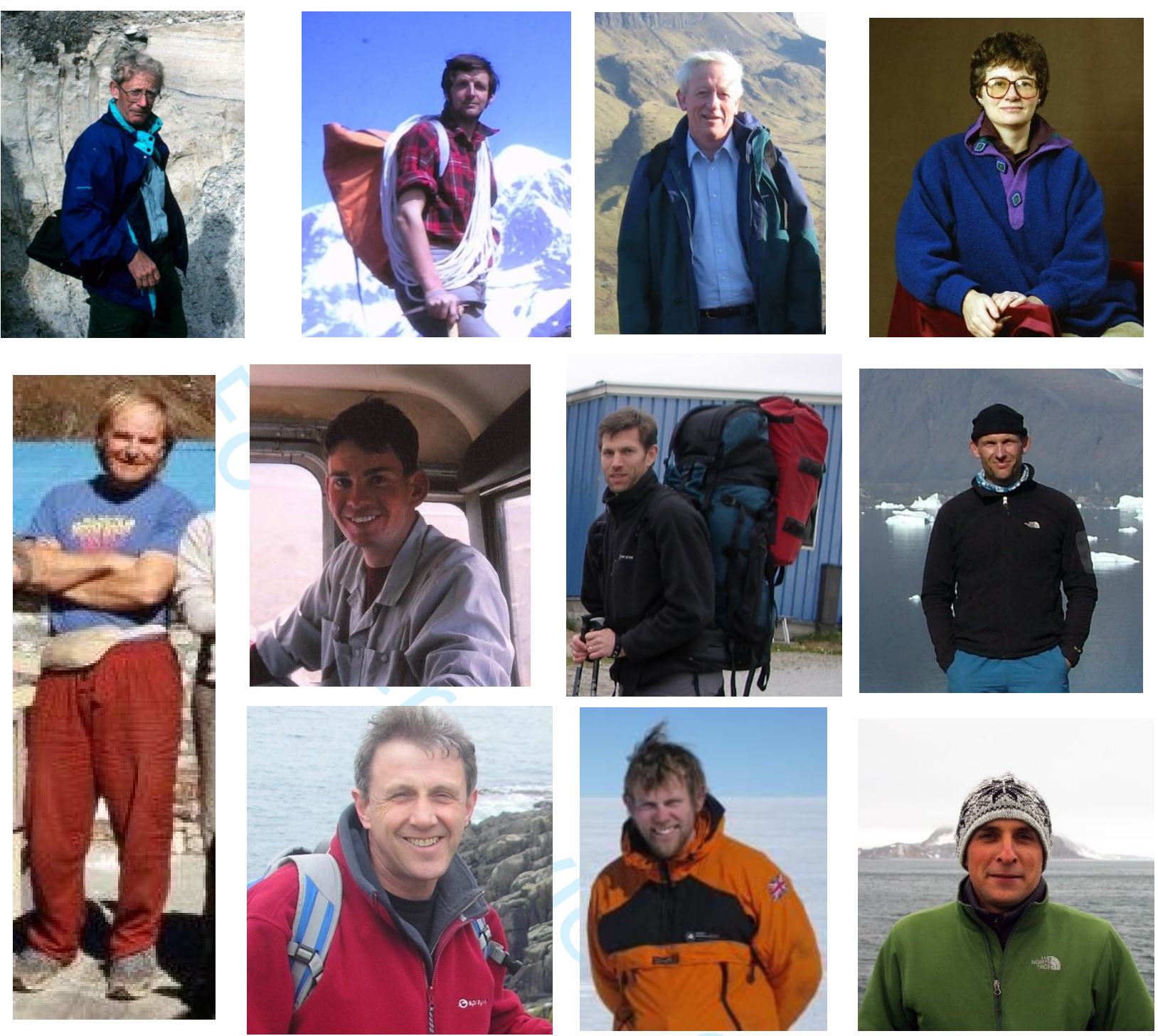

Figure 12. Photographs of the Aberdeen glaciologists at some point during their time in the Department, from top left to bottom right: Chalmers Clapperton, David Sugden, Al Gemmell, Judith Maizels, Doug Benn, Nick Spedding, Doug Mair, Brice Rea, Alastair Dawson, Rob Bingham and Matteo Spagnolo. 
